\title{
SOME SERUM BIOCHEMICAL, HORMONAL AND PROTEIN PROFILE STUDIES ON BUFFALOES AND CATTLE SUFFERING FROM MYCOTOXICOSIS AND/OR BRUCELLOSIS
}

\author{
Abdel Fattah, Sh.M.; El-Dieb., M.K.M.*; Swiefy, A.S.**; \\ Abu-Self, F.A.*** and Helal, A.D.**** \\ Siallonal Researcts Center (Food pollutunts Depl.). \\ -Antinal Heallh Research instilute (Zagg, Branch, Chem. Dept.). \\ * Animal Proxtuction Research Instilute. \\ *a Fiachlly of girls. ectence and cducatlon (Ein Shams Lniverslly). \\ *..*Animal Jeallit Research Inslitute (Benha branch, Chem. Depl.).
}

\begin{abstract}
SUMMARY
In a privale farm. the effects of mycotoxicosis and/or brucellosis were studied on bujiztoxs and centle. From cach of spectes lone month afler abortion or normal parturition) twenly animals were divided into four equal groups. The first group was served as contral antrials, the second group was non-infected animals but the mycotoxins were delected in their serum. the third group was naturally brucella infected animals and the fourth group uxas both nalually uricella infected and mucotoxtn poisoned animats. Brucellosts was identifted serologically and from the clinical signs. Mycotoxicologkal, serological, homonal. serum protein electrophorettcal and biochemical stitdies were canted out. Results indicated that the mycotoxusts whlch uere detected in serum of carle and kuffaloes are aflatoxin-Bl octuataxin-A and fumonsin.BI by a concentrathons in bufjaloes mone than that in cattle. In contrast, the higher brucelta titers were detecled in cattle than that in buffaloes. Mycotaricosts and/or brucellosis could induced reproductive disturbances due to the changes of serum progesteron, estrogen. ahiodothyronin (T3) and thyraxth (T4) hormones], immunosuppresston by mycataxtcosis in buffaloes (because of gamma globulinemia). metabolic disturbances fdue to the increase of T3. T4 ard totat tipids), and llver dysunction in buffaloes fdue to the increase of tolal bilirubin concentration and the actulty of AlT enzyme). The mycotoxins should be chicked in regions of high inciflence of briceliasis in onter to conirolling or dininuting the mycotoxicosls which is a predispasing siress foctor for occurrence of infections by their innunodepressunt properties.
\end{abstract}




\section{INTRODUCTYON}

Fubgh may contaminale amilnal fered. eertain rungl secreted sccondayy metabolites which are (mxic for aninkis ankl humbur (Miller, 1995). Annong the identified mycotoxins. Nuc of which are ol special toxicological muorlance are Allaloxins. deoxynlualenol, Zearalenonc, fumonsims. and ocldartitoxins (Anonymous, 1992). Alatoxlns are Immunotoxje by depressing the cell medlated inmunc response (Diotert et al., 1985) redueing hurmonal imnune response (Tang et al., 1995) and reduchng prtury haemeglutum responsc (Ghosh et al., 1991). Ohratoxins induced nephrotoxicity, careingenixily, teratogeniclly and inmunotoxiclty (Kuiper, 1908). Fumonstns induced cquine leuxoencephalomalacla, pulmonary ederna, Immunotoxlcty and carchogenlrity (Harrison et 11., 1990). Brucellosis is an important contaglous discase Infecting human and anInals and muluced great losses in animal production allover the world (Radoetite et al. 2000).

In a sinifiar study in sheep and goat in Kalcubla prownce (Egypt), Abdel Fattah et al., (2004) identified several mycotoxins in animal feed mixture (concentrates) and malze which were: Aflatoxin-b) $(0.642-0.355 \mathrm{mg} / \mathrm{kg})$, Ochratoxin-A $(0.143-0.231 \mathrm{mg} / \mathrm{kg})$ and fumonstn-BI $(0.125$ $0.274 \mathrm{mh} / \mathrm{kg}$. also lincy fonnd that $\mathrm{B} 2.618$ of mycotoxin polsoned sheep and goats were inferted with brucellosis. whike low of rion inlecked shcep and goats were mycotoxin poisoned, and they conchuder that mycotoxicosis was onc the predisposing factor for brunclla infectom.

The atm of the prescht study is to studyng the homonal, biochconical and Iminunotogical changes that could be indueed by urucelrosis arid/or inycotoxdcosis In buflaloes and cattle in order to understanding the intercorrelations between the two diseases and their nefative eflects of

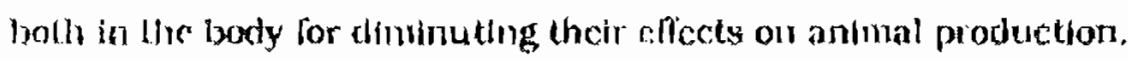

\section{MATERIAL AND METHODS}

\section{Scrological Diagnosis of Brucelloels:}

Serological diagnosis of bnicellosis was carricd out on serum samples from aborted buftaloes and calle which showed the clinical signs of brucellosis and could be differentially dlagnased from othei discases causing abortion based on thetr chntcal signs and serological charactcristics according to Blood at al., (1979) senum samples were colleeted from a private farm in Kaleubla governorate. one month after abortion or nomal parturition, and the Buter acidifted plate antIgen (BAPA) test (Anon, 1984) was used for the primary diagnosls of brucella infected animals. The tube aggitutination test (TAT) was carried out which modifled to start with a dilutions of 1) 10. and the Rivanol test (Alton et al., 1988) were used for adduonal confmrmatuon of the serological identifleation of brucellosis. 
Abdel Fattah, Sh.M.; et al...

\section{Mycotoxin andysis:}

The standard of Alatuxin-BI (AFBI), Ochratuxin-A (OA) and Fumonsin-BI (FBD1) were ob-

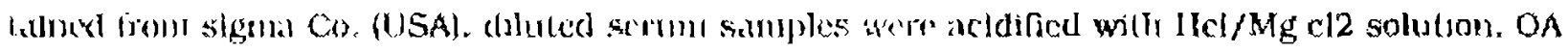

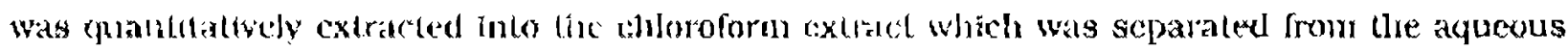
schum by echuffegation, deth eiforoform extract was wakhed once wilh wates to remove the dissolved arid. then drted under is steam of niluogen gas. the drted rasidues were reconstituted in chloroform atul the eone. of OA were detemmed nuorodensitometrleally. The Al'BI was extractcl and alcicrmined fluorodensitometrlcally, but fumonsin- $B$ I was extracted and determined using the high performance Jiquld chromatography (IIPLC). All mycotoxdns were determined according to AOAC (1080).

The Tested Groups of Animals: Twenty lemale and twerrty caws lone month after abortion or nomal parturtionl were uscd. From cich species the antmals were dlyided into 4 equal groups 15 anlmals/groupl as follow: The $1^{\text {st }}$ group as the normal control group, the 2 nd group was my* cotoxin potsoned amimals. the $3^{\text {rod }}$ group was naturally brucella Infected animals 11 month afur abution) and the $4^{\text {th }}$ gtoup was naturally brucella infected and mycotoxin polsoned caws (I rmonth after abortton].

\section{Estimation of some serum constituents:}

\section{(A) Some Serum Hormones;}

The radioimmuno-assay inethod was used for deternination of prolactun, progesteron, estrogen, triiodolhyronin (13) and thyroxin (T4) hormones (Challis et al., 1973).

\section{(B) Serum Protein Electrophoresls Analysls:}

The polyacrylanide Cel Electrophoresis texhnque (Gordon, 1983) was used for fractionation of serumi proteln into the tifferent protcin fractions.

(C) Some Serum Blochemlcal Constltuent:

The concentuations of lutal protein (Doumas et al., 1971). total liplds (Schmit, 1964) and the latal bllirubins (Jendrassikl et al., 1983\} and the activty of Alaninc aminotransferase enzync (Reitman and Frankel, 1957), were determined spectruphotometrically,

\section{Statistical Analysig:}

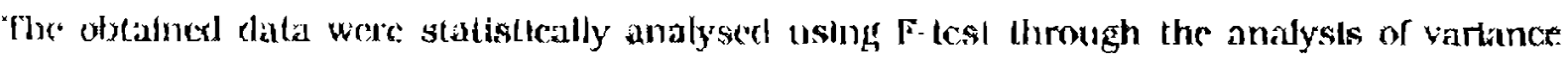
(ANOVA), and the student's i-Lest according to Snedecor and Cachran, (1969). 


\section{RESULTS}

A- Mycotoxin levelo and brucella antibody titers; The serum mycotoxin increased in buffa. locs Lhan that of caule especially fumonsin Bl, opposttely, the higher antbody tices of brucella mercased in exitte than that in buffalocs (Tabie, 11 .

\section{Serum Hormonal Changes:}

(1) Prolactin hormone: No significant change in seium prolactin hormoac between the groups of buftaloes and callik.

(2) Progesteron hormone: Brucellosis Induccd significant decrease of progesteron hormone In bulfaloes and catlle than normal control, but nycotoxjensto induced signincaut incrcase In progesteron hormone than that of the normal control in elther buffaloes or cattle.

(3) Estrogen hormone: Mycoloxicosis and/or brucellosls induced signilicant decrease of estrogen hormone than that of the norral control buffaloes or cattle.

(4) Tritodothyronin $\left(T_{3}\right)$ Hormone: Only in buftaloes, brucellosis Induced significant increasc of $\mathrm{T}_{3}$-hormone than that of the normal control buffaloes, but there was no signillcant change of $T_{3}$ hormones in the serum of catilc groups.

(8) Thyroxin $\left(\mathrm{T}_{4}\right)$ Hormone: The serum diyroxtn hormone was signifeantly increased with mycoloxieosis and/or bruccilosis (in most cases) than that of the normal control bullatoes and cattle (Tables 2 and $3 i$.

(C) Some Berum Blochemlcal Constifuents:

1. Alanine amlno transferase (ALT) Enxyme activity: ALI engyne aclivily slgnificanlly Incrcased by mycotoxicosis and/or bruccilosis in the serum of buffaloes than that of the norinal control antuals, but ALT" activity does not changed in catte groups.

2- Total Bllirubla: In buffaloes, only brucellosis induced signincant Increase in serum bllirubin than that of normal control animals but docs not changed in the serum of eatte groujes.

3- The Total Lpida: Only In butTaloes. the tolal llplds were signilleantiv increased in animals suffering from nyycotoxicosis and/or bruecllosis than that of the normal control buffaloes. but it does not slgnincantly changed in the scrum of cattle groups.

4- Total Proteia: Mycotoxicasis signifncantly decreasing the tolal proteln (in unost cases) than 
nomtal control buffaloes and catue. In cattle, brucellosis Induced significant increase of total protein than normal control catte (Tables 4 and 5 ).

(D) Serum Protein Electrophorr. dis (proleín Fractions):

1. Albumin: In buthaloes. therc were no significant cliange in serun albunin between groups, but in cattle the brucella Infected animals showed significant increases in serum albumin than that of control cattle.

2- Total Globullns: In buffaloes, there were no signiflcant change in serum total globulins between groups, but in cattie, the mycotoxin polsoned animals (brucella infected or non infected) showed significant decrease In the serum total globulins than that of control cattle.

3- Alpha (a) Globulin Fractian: In buffaloes, no slgnificant change of a-globulins between groups. but in cattle. mycotoxicosts and/ar bncellosis induced significant increase of the r-globulins than that of control cattle.

4- Beta (B) Globullos Fraction: In elther buffalo or cattle, the mycotoxin polsoned and/or brucclla infected animals showed signilicant decrease of $\gamma$-globulins than that of control animals.

5- Gamma ( $y$ Globulin Fractions (Immunogtabulins): In case of non-infected bulfatoes. Uhe mycotoxin polsoned animals showed significant decrease of $\psi$-gjobulins than control. also in brucella infected buffaloes, the mycotoxin poisoned atimals showed signifleant decricasc In $\gamma$-globullns than that of only brucella infected buifaloes. also bruccllosis (with or witl1out mycotoxicosis) Induced significant Increase of $\gamma$-globullns than that of non-infected buflaloes.

In case of catte, anycotoxlcasis not significantly decrease $\gamma$-globulins than that or control cat. Ue, but brucellosis could indured signincant increase of $\gamma$-globutins than that of control cattle (Tables 6 and 7).

\section{DISCUSSTON}

The different fungl may polfute the environment and become found in the raw nutrittve sub. stances and other blological materals, human lood. animal foed and feed-or lood-products. Also such nutritive materials may kept under unfavourable condluton favouring the growth of differcnt fungi. Soine types af lungl could secreung loxic materals called mycotoxins and consequent* by by thcir consumption induce a disease called mycotoxicosis (Naller, 1085). Polsoning with 
mycotoxins may be diftered from other potsoning materlals. that the latter may be seen fln many cases] with naked eye or Identuled by thelr spectic odours or tastes, and may tnduce specinc acule or ehronle toxdelty wilh specinc elinical signs. and may induced intentlonally or uninten. thonally duc th the known circumsinices, all these dala may lcad to scarching for the sounce of toxicity incl consequently preventing or diminuting it caster than that of mycotoxjcosis fwhich is whidy spread and more dimeult to detcct espcclaliy in chronle or long term toxicitest. Mycotoxloosis may be the end trial for understanding the real healthy problen 10 andmals and poulltry, because the symptoms were non-specifle that th may be tmmunodepressants to different infccthous diseases (Dletert et al., 1985) or inducing loss of welght without disunctive other clinical signis (CAST, 1989).

So Ulat, nyycotoxicosis should need further. dirncult and complicated efforts for deminuting it to acceptable limits rendering it to be practically non-significantly cffecllve. The first step for recaguizing sucir problein to understanding the toxicological propertles of nycotoxins in Egyptan anlmals (such as cattle aud buffaloes) under the eurrent Egyplian environment.

The farm anthals inay stulfering from sone infectlous discases such as brucellosis which is an important contagious and zoonotic diseasc lifecting anlmals and human, the disease may cause grcat losses in animals that preventung the reproductive functions and consequently reducing the animall produetion allover the work (Radostits et al., 2000). So Uhc current study tried to And ccrtain relationslips between the bruccllosts and mycotoxicosis in buffalucs and cattle from the point of animal healus.

An important rclaLtonship betivcen Uie inycotoxicosis and lyucellosis could be delected in shcep and goats through a prevlous study by Abdel Fattah et al., (2004) which indicated that the mycotoxins could be detected fronr $82.6 \%$ of brucella tnfected antrmals, opposttely, it could be detected from $10 \%$ ol non-tnifected antmals, and it could be coneluded that mycotoxicosis induced imnunosuppression to brucclla infection In goat and shecp because of the significant hypogarnmaglobulinemia in thesc animals. Sucly conclusion could be detected also by the present study, where the inycotoxicosls could signincantly reduced the gamma ( $($ ) globulins (immunoglobulinemial in brucclia infected and non-infeeted bulfaloes than that of control animals, while in catle the decrcase of $y$-globulins was non-signilfcant. The immunodepressant property of myeotoxicasis could be recorded also by the preylous studles. that the aflatoxicosis may depressed the ccll-mediated Immune responses (Dletert et al., 1995), reduced Igc (Tang et a., 1905) and reduced the primary haomagglutinin response (Ghosh et al., 1991]. Also, the oehratoxicosis (Kulper, 1996) and Uje fumonsin-B1 (Harrleson ot al., 1900) Jave reported to induce immunosuppressive actions, so Urat the Immunosuppression should be considered an Important predls- 
bostng factor for Increastng the incldence of infertlous diseases and it unay roduced also the proshachou elliclojey In arrinals (CAST, 1989).

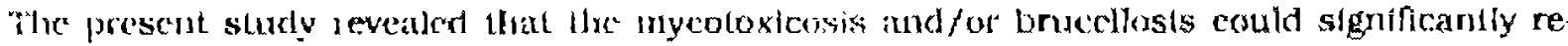
duced the beta (F) giobulin fraction. Wian that of normal control buffaloes and catte some gam-

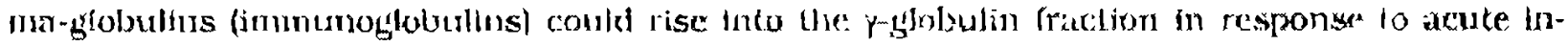
flarnnatory diseases. autulmmune disease, hemolytic anemb and tron veficlency (Kaneko, 1989).

The present study reveated that the inycotoxdeosis and/or brucellosis could signlicantly increascd the alpha (B) glubulin Iraction of the senum protein than that of the control buffalces and cattie. The elevated levels of some $\gamma$-globulins have been reported whth protein cataljollsm or with adrcusl stimulation (Schajm, 1975) or with some toxic inatertals (Dolezalova et al., 1983).

The present serological diagnosis of brucellosis revealed that there wcre significant increase of the anthody titres agahnst brucellosis in cattle than that of buffalocs. Oppositely, the serum levels of nycotoxins (especially rumorsist - Bl) were decreased in cattle than that deteeted in buffaloes. Filhis pointed to a reverse rclatlonsh/p betrveen mycotoxin coneentration and the spectife anthbodies (specinc immunoglobulins) agatnst brucellosls. Icading to the suggestlon that the myeotoxins are immunosuppresslve to bruccllosls in buffaloes and rattle as previously recoded In slleep and goats (Abdel Fattah et al., 2004).

The present work revenled that the mycotoxicosis Induced a slight [non-slgnifleant] dectease in ptluilary prolactin homone and revealed a significant decrease of estrogen homone In cattle and bufialoes than that of the nornal animals. But Abdel Fattaln et al., (2004) recorded a sigolfeant decrease of the prolactin hormone with slight (non-gignifleant) inerease of progesteron homnone in shcep and goats. The major effects of prolacun on the secrelion of the follicle sthululaling bormone (FSH) and the lutelnizing hormone (LH) appear to be exerted by Inhubluan of the sccretion of the Gonatotropin releasing hormone (GnRH) by pltuitary gland, so that there was a reverse relationship betweat the prolactir level and the levels of FSH and LH-pitultary hormones, and consequently the wvatian progesteron hormone (Cheung, 1983). The cInical signs of (aculc) mycotoxicosis ln citlle may be non-spceific as reduccd milk yleld, increased aborton or embryonie mortalitles. silent lieal inegular estrus eycles, decreased conception rates duc to the inducion of endocrioc and neuroendocrlie disturbances (CAST, 1089). so that, the changes in botli progesterone ar estrogen (as induced by mycotoxicasis and/or bruecllosts) may lead to disturbances in the nomial ovulatory cycle, and eonsequendy lead to the reproductuve fathure (Valtukaltis et al., 1871 ).

The present work revealed that elther mycoloxicosis or brucellosls could induced signlficant 
hercase of thyroxin hormone $\left(\mathrm{T}_{A}\right)$ in catte and bultaloes than control animals. but the triodo.

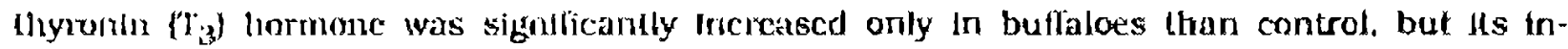
rrrased in calle was non-signlfieant. The hyperilhyruidism tnay Induec loxte golter which may leari lu cxecssive netabolic reaction is ind consequchely losing of weight (Georgleva. 1989). The

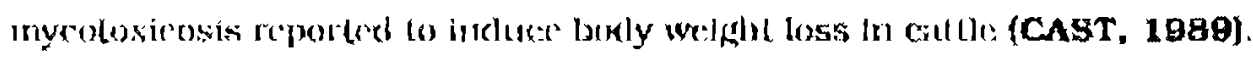

In bulfaloes, bucellosis induced significan increase of stanine ambno transferase (ALT) enzyme activity, culat bilinubin and colal lipids and induecd signincant decrease in local proteln concentiation. Similar results could be detected in shesp suffered from brucellosis by Helal and Abdel Fattah (2003). this rcsuits leading to suggeston dlat the bruccllosis Induced hepalle dysfunction and hyperlipidemia and bypoprotelnemia in bullatoes than that of calle. The Inereased ALT-enzyme activlty and lolal bflirubin concentration are indicaluve of hepatic dysfurbetion as reported by Kachman and Moss (1978).

The mycotoxicosls induced sigintleant increase of tolat lipids in bultaloes and slgnificant deercasc of tolal protcin in bolh buffaloes and calte than llat of control antmals. The hyperlipidemia may be induced because of the inicrfenence wilh lipla metabolism, or with xenoblatles (Stroev, 1988), or after cstrogen, progestcron. glueocorticold or sucrose administralion (Young et ah., 1975). The mycotoxIn lumonsin-Bl could Induced a mild hepallc damage (Oswetler et a1., 1993).

Based on the present study, It eould be concluded that the mycoloxteosis induccd immurosuppresston cowards brucellosis (due to baduction of hypogammaglobullnemia) in buffaloes than that In callic. and induced metabollc and reproductive disturbances (because of the hormonal changes), but brucellosis induced hepatic dysulindton in buffalocs las a tesult of some serum biocherrieal ehanges). 
Table (1): The serum levels of different mycotoxius in brucella infected buffaloes and cattle as seralogically diagnosed by tube agglutination and rivanol tests.

\begin{tabular}{|c|c|c|c|c|c|c|c|c|}
\hline \multirow{3}{*}{\multicolumn{2}{|c|}{ Groups }} & \multicolumn{3}{|c|}{ Serumi levels of mycoloxins } & \multicolumn{4}{|c|}{ Serolagical lests of bruealta } \\
\hline & & \multirow{2}{*}{$\begin{array}{l}\text { Alataxin } \\
\text { Bl(AF B B) } \\
\text { (Agiml.) }\end{array}$} & \multirow{2}{*}{$\begin{array}{c}\text { Ochralaxin- } \\
\text { ( } 10 \mathrm{~A}) \\
(\mathrm{ng} / \mathrm{ml},)\end{array}$} & \multirow{2}{*}{$\begin{array}{c}\text { Fumansin } \\
\text { I ( } \mathrm{FBI}) \\
\text { (ng/ ml.) }\end{array}$} & \multicolumn{2}{|c|}{ Tube aget Test } & \multicolumn{2}{|c|}{ Riranal lesI } \\
\hline & & & & & $\begin{array}{l}\text { Tiker } \\
\text { ronge }\end{array}$ & $\begin{array}{l}\text { Long to } \\
\text { value of } 1 \mathrm{he} \\
\text { reciprocal } \\
\text { titers }\end{array}$ & $\begin{array}{l}\text { Titer } \\
\text { range }\end{array}$ & $\begin{array}{l}\text { Lang } 10 \\
\text { values of the } \\
\text { recipracal } \\
\text { (iter }\end{array}$ \\
\hline \multirow{2}{*}{ Bufruloes } & $\begin{array}{c}\text { Combon } \\
\text { group }\end{array}$ & $\begin{array}{c}0.00 \\
\pm \\
10.00\end{array}$ & $\begin{array}{c}0.00 \\
\pm \\
0.010\end{array}$ & $\begin{array}{c}0.00 \\
\pm \\
0.001\end{array}$ & 0.00 & $\begin{array}{c}0.00 \\
\pm \\
0.00 \\
\end{array}$ & 0.180 & $\begin{array}{c}0.00 \\
\pm \\
0.00\end{array}$ \\
\hline & $\begin{array}{l}\text { Iirucella } \\
\text { intecled } \\
\text { group }\end{array}$ & $\begin{array}{c}201 \\
\pm \\
3.162\end{array}$ & $\begin{array}{c}178 \\
+ \\
9.81\end{array}$ & $\begin{array}{l}197 \\
\pm \\
7.62\end{array}$ & $\begin{array}{l}1 / 20- \\
1 / 40\end{array}$ & $\begin{array}{c}1.482 \\
\pm \\
0.066\end{array}$ & $\begin{array}{l}1 / 100- \\
1 / 400\end{array}$ & $\begin{array}{c}2,301 \\
t \\
0.085\end{array}$ \\
\hline \multirow{2}{*}{ Caule } & $\begin{array}{l}\text { Concral } \\
\text { group }\end{array}$ & $\begin{array}{c}0.00 \\
\pm \\
0.00\end{array}$ & $\begin{array}{c}0.00 \\
\pm \\
0.00\end{array}$ & $\begin{array}{c}0.00 \\
\pm \\
0.00\end{array}$ & 0.00 & $\begin{array}{c}0.00 \\
\pm \\
0.00\end{array}$ & 0.00 & $\begin{array}{c}0.00 \\
+ \\
0.00\end{array}$ \\
\hline & $\begin{array}{l}\text { Drucella } \\
\text { Infected } \\
\text { graup }\end{array}$ & $\begin{array}{l}211 \times 5 \\
\pm \\
8.2 .16\end{array}$ & $\begin{array}{c}169 N 5 \\
5 \\
3.72 \\
\end{array}$ & $\begin{array}{c}171^{4} \\
\pm \\
8.60 \\
\end{array}$ & $\begin{array}{c}1 / 40 \\
1,80\end{array}$ & $\begin{array}{c}1.903^{\star} \\
\pm \\
0.093\end{array}$ & $\begin{array}{c}1 / 200- \\
1 / 400\end{array}$ & $\begin{array}{c}7 \times 42 \\
\pm \\
0.054\end{array}$ \\
\hline
\end{tabular}

N.17. * = Significant change in serum inycotoxins or in the specific antibody titers (log io values) between brucella infected buflaloes and brucella infected caltle), ** = Highly significant change belween means of brucella infected cantle and brucella infecled buffaloss. N.S. = Non-significant change. 
Abdel Fattah, Sh.M.; et al...

Table (2): Effects of mycotoxicosis and/or brucellosis on some serum Hormones of buffaloes

\begin{tabular}{|c|c|c|c|c|c|}
\hline Groups & $\begin{array}{l}\text { Proluetin } \\
\text { hormone } \\
\text { (‥I.Luml) }\end{array}$ & $\begin{array}{c}\text { l'rapes/erone } \\
\text { hormonc } \\
\text { (nginal) }\end{array}$ & $\begin{array}{l}\text { Estrogen } \\
\text { horalune } \\
\text { engtmli }\end{array}$ & $\begin{array}{l}\text { Triodothyronin } \\
\text { (T3) hormune } \\
\text { (nmoln.) }\end{array}$ & $\begin{array}{l}\text { Thyroxin (T } \downarrow) \\
\text { lormone } \\
\text { (um } 1 / \mathrm{L} \text {. })\end{array}$ \\
\hline $\begin{array}{l}\text { Control } \\
\text { (nurmal) group }\end{array}$ & $\begin{array}{c}1.500 \pm 0.126 \\
\wedge\end{array}$ & $\begin{array}{c}6.900 \pm 0.330 \\
\wedge \\
\end{array}$ & $\begin{array}{c}1248+8,94 t \\
A\end{array}$ & $\begin{array}{c}10.00 \pm 0.894 \\
A\end{array}$ & $\begin{array}{c}72.600 \pm 3.622 \\
\mathrm{~A}\end{array}$ \\
\hline $\begin{array}{l}\text { Mycalaxin } \\
\text { poisoned group }\end{array}$ & $\begin{array}{c}1.450 \pm 0.124 \\
A\end{array}$ & $\begin{array}{c}9.200 \pm 0.707 \\
\text { H }\end{array}$ & $\begin{array}{c}1613 \pm 15,221 \\
B\end{array}$ & $\begin{array}{c}10.70 \pm 1.004 \\
\mathrm{~A}\end{array}$ & $\begin{array}{c}93.300 \pm 6.957 \\
\mathrm{BC}\end{array}$ \\
\hline $\begin{array}{l}\text { Brucelly infected } \\
\text { group }\end{array}$ & $\begin{array}{c}1.750 \pm 0.268 \\
A\end{array}$ & $\begin{array}{c}3.200 \pm 0.291 \\
C\end{array}$ & $\begin{array}{c}211 \pm 13.914 \\
C\end{array}$ & $13,80 \pm U .967$ & $\begin{array}{c}85.700 \pm 7.211 \\
\mathrm{AB}\end{array}$ \\
\hline $\begin{array}{l}\text { Brucella infected } \\
\text { mycotoxia } \\
\text { poisonct uroup }\end{array}$ & $\begin{array}{c}1.600 \pm 0.089 \\
A\end{array}$ & $\begin{array}{c}3.500 \pm 0.558 \\
C\end{array}$ & $\begin{array}{c}295 \pm 6.325 \\
15\end{array}$ & $\begin{array}{c}17.900 \pm 1.640 \\
C\end{array}$ & $\begin{array}{c}104.32 \pm 11.540 \\
C\end{array}$ \\
\hline$L S D(P<0.05)$ & NS & 0.791 & 19.211 & 1.648 & 14.544 \\
\hline
\end{tabular}

N.B.: The dillerent capital litters in columns denote the presence of significant clange between meals (at $P \leq 0.05$ ), LSO = least significant diflerence between means (at $P$ $<0.05$,

Table (3): Effects of mycotoxicosis and/or bruceltosis on some serum hormones of cattle

\begin{tabular}{|c|c|c|c|c|c|}
\hline Group & $\begin{array}{l}\text { Prolaciìn } \\
\text { hurnone } \\
\text { (N.1.U./mi) }\end{array}$ & $\begin{array}{c}\text { Progesterane } \\
\text { bormone } \\
\text { (ng/m) }\end{array}$ & $\begin{array}{c}\text { Estragcn } \\
\text { hormone } \\
\text { (ag/mi) }\end{array}$ & $\begin{array}{l}\text { Trifodn theyronin } \\
\text { (T3) hormone } \\
\text { (nmol/L.) }\end{array}$ & $\begin{array}{c}\text { Thyroxia (T } 4) \\
\text { hormone } \\
\text { (nmid/L.) }\end{array}$ \\
\hline $\begin{array}{l}\text { Contrisl } \\
\text { (norminl) group) }\end{array}$ & $\begin{array}{c}1.100 \pm 0.063 \\
\mathrm{~A}\end{array}$ & $\begin{array}{c}54.00 \pm 3.298 \\
\mathrm{~A}\end{array}$ & $\begin{array}{c}1293 \pm 20.396 \\
A\end{array}$ & $\frac{15.700 \pm 1.523}{A}$ & $\begin{array}{c}110.800 \pm 6.325 \\
\wedge \\
\end{array}$ \\
\hline $\begin{array}{l}\text { Mycentoxin } \\
\text { poisoned group) }\end{array}$ & $\begin{array}{c}1.070 \pm 0.146 \\
\mathrm{~A}\end{array}$ & $\begin{array}{c}62.2011 \pm 4.20 \overline{9} \\
13\end{array}$ & $\begin{array}{c}1043 \pm 13.796 \\
13\end{array}$ & $\begin{array}{c}16.600 \pm 1.844 \\
A\end{array}$ & $\begin{array}{c}159.8 \pm 10.249 \\
n\end{array}$ \\
\hline $\begin{array}{l}\text { Brucella infected } \\
\text { group }\end{array}$ & $\begin{array}{c}1.190 \pm 0.258 \\
A\end{array}$ & $\begin{array}{c}49.400 \pm \$ .261 \\
C\end{array}$ & $\begin{array}{c}1319 \pm 17.0888 \\
C\end{array}$ & $\begin{array}{c}17.500 \pm 3.578 \\
A\end{array}$ & $\begin{array}{c}154.400 \pm 9.265 \\
B\end{array}$ \\
\hline $\begin{array}{l}\text { Brucellit Infected } \\
\text { \& myculoxin } \\
\text { poisoned group }\end{array}$ & $\begin{array}{c}1.200 \pm 0.029 \\
1\end{array}$ & $\begin{array}{c}53.00 \pm 3.153 \\
\mathrm{AC}\end{array}$ & $\begin{array}{c}1549 \pm 24.518 \\
D\end{array}$ & $\begin{array}{c}18.300 \pm 2.039 \\
A\end{array}$ & $\begin{array}{c}177.300 \pm 6.747 \\
C\end{array}$ \\
\hline $\operatorname{LSU}(P<0.05)$ & 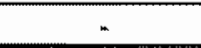 & 4,043 & 20.190 & $*$ & 9.410 \\
\hline
\end{tabular}

N.B.: The different capital litters in columus denote the presence of significant chalue belween means (at $P \leq 0.05$ ), LSD = least significant difference between means (al $P$ $<0.05)$. 
Table (d): The effeets of mycotoxicosis and/or brucellosis on the different clectrophoretically separated scrum protein factions of butraloes

\begin{tabular}{|c|c|c|c|c|c|c|}
\hline Grpuy & $\begin{array}{c}\text { Alpha }() \\
\text { gloluthas (git) }\end{array}$ & 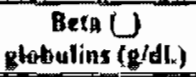 & $\begin{array}{c}\text { Cumma (fo) } \\
\text { globalins (ofdl. }\end{array}$ & $\begin{array}{l}\text { [rotal glabulins } \\
\text { (g/dxl) }\end{array}$ & $\begin{array}{l}\text { Albumin } \\
\text { (g/dl) }\end{array}$ & $\begin{array}{c}\text { Tatal procein } \\
\text { (didl) }\end{array}$ \\
\hline $\begin{array}{l}\text { Contral } \\
\text { (normsl) group }\end{array}$ & $1.712 \pm 0.179$ & $\begin{array}{c}1.652 \pm 0.162 \\
A\end{array}$ & $\begin{array}{c}1.159 \pm 0.064 \\
A\end{array}$ & $\begin{array}{c}1.521 \pm 0.143 \\
A\end{array}$ & $\frac{3,784 \pm 0.348}{1}$ & $\begin{array}{c}8.30 \mathrm{H} \pm 0.289 \\
\mathrm{dC}\end{array}$ \\
\hline $\begin{array}{l}\text { Alycoloxía patsoned } \\
\text { group }\end{array}$ & $\begin{array}{c}1.97 d \pm 0.200 \\
A\end{array}$ & $\begin{array}{c}0.835 \pm 0.036 \\
\mathrm{~B}\end{array}$ & $0.695 \pm 0.111$ & $\begin{array}{c}3.594+0.291 \\
1\end{array}$ & $3.519 \pm 0.912$ & $\begin{array}{c}7.023 \pm 0.289 \\
0\end{array}$ \\
\hline $\begin{array}{l}\text { Bructis iafected } \\
\text { Broup }\end{array}$ & $\begin{array}{c}2.595 \pm 0.063 \\
A\end{array}$ & $\begin{array}{c}0.114 \pm 0.032 \\
C\end{array}$ & $\begin{array}{c}1.932 \pm 0.244 \\
C\end{array}$ & $\begin{array}{c}4.961 \pm 0.226 \\
\mathrm{~A}\end{array}$ & $\begin{array}{c}3.656 \pm 0.510 \\
A .\end{array}$ & $\begin{array}{c}8.617 \pm 0 . \overline{115} \\
1\end{array}$ \\
\hline $\begin{array}{l}\text { irucella infecied } \\
\text { mycoroxin polioned } \\
\text { grage }\end{array}$ & $\begin{array}{c}1.034 \times 0.728 \\
A\end{array}$ & $\begin{array}{c}0.766 \pm 0.143 \\
B\end{array}$ & $\begin{array}{c}1.564 \pm 0.138 \\
D\end{array}$ & $\begin{array}{c}4.366 \pm 0.231 \\
A\end{array}$ & $\begin{array}{c}3.357 \pm 0.375 \\
A\end{array}$ & $\begin{array}{c}7.923 \pm 0.128 \\
C\end{array}$ \\
\hline LSI) $(F \leq 0.06)$ & 45 & 9.256 & 0.781 & $\mathrm{NS}$ & $\mathbf{N S}$ & 0.197 \\
\hline
\end{tabular}

N.B.: The different capilal litters in columns denote ilie presence of significant change

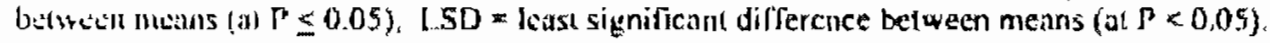

Table (5): Efrects of mycotoxicosis and/or brucellosis on the different clectropharetically separated serum protein factions of cattle

\begin{tabular}{|c|c|c|c|c|c|c|}
\hline Corpus & $\begin{array}{c}\text { Alpha }(0) \\
\text { Sobulias }(g / d))\end{array}$ & $\begin{array}{c}\text { Beta LJ } \\
\text { globulios (gydl.) }\end{array}$ & $\begin{array}{c}\text { Comma (p) } \\
\text { lobutias (otol.t) }\end{array}$ & $\begin{array}{l}\text { Tatal globulias } \\
\text { (g'di) }\end{array}$ & $\begin{array}{l}\text { Albumin } \\
\text { (afdi) }\end{array}$ & $\begin{array}{c}\text { Tatal protein } \\
\text { (edell.) }\end{array}$ \\
\hline $\begin{array}{l}\text { Control } \\
\text { (nomeal) grawp }\end{array}$ & $\begin{array}{c}0.117 \pm 0,030 \\
A\end{array}$ & $\begin{array}{c}2.078 \pm 0.038 \\
A\end{array}$ & $\begin{array}{c}1.4 .30 \pm 0.084 \\
A C\end{array}$ & $\begin{array}{c}4.225 \pm 0.252 \\
A C\end{array}$ & $\begin{array}{c}3.467+0.116 \\
A\end{array}$ & $\begin{array}{c}7.692 \pm 0.086 \\
\times\end{array}$ \\
\hline $\begin{array}{l}\text { Mlycalnion poisoned } \\
\text { groull }\end{array}$ & $\begin{array}{c}1.151 \pm 0.063 \\
8\end{array}$ & $1.452 \pm 0.152$ & $0.952 \pm 0.169$ & $\begin{array}{c}1.538 \pm 0.292 \\
8\end{array}$ & $\begin{array}{c}3.282 \pm 0.564 \\
A\end{array}$ & $6.8 w \pm \overline{6} .352$ \\
\hline $\begin{array}{l}\text { brucella infected } \\
\text { eroup }\end{array}$ & $\begin{array}{c}1.671 * 0.033 \\
\mathrm{C}\end{array}$ & $\begin{array}{c}0.761 \pm 0.696 \\
C\end{array}$ & $\begin{array}{c}1.129 \pm 0.231 \\
6\end{array}$ & $\begin{array}{c}+.553 \pm 0.357 \\
\wedge\end{array}$ & $\begin{array}{c}3.611 \div 0.555 \\
8\end{array}$ & $\begin{array}{c}9.364 \pm 0.116 \\
c\end{array}$ \\
\hline $\begin{array}{l}\text { Bruceila itlected a } \\
\text { mscolosin poironed } \\
\text { group }\end{array}$ & $1.215=0.031$ & $1.121 \pm 0.267$ & $\begin{array}{c}1.361 \times 0.276 \\
C E\end{array}$ & $\begin{array}{c}+100+6203 \\
C\end{array}$ & $\begin{array}{c}3.523 \pm 0 .+4.5 \\
B\end{array}$ & $\begin{array}{c}7.923 \neq 0.221 \\
\wedge C\end{array}$ \\
\hline$L S D\left(p^{\prime} \leq 1.05\right)$ & a.o78 & 0.560 & $0 \times 26$ & $0 . \overline{332}$ & 0.223 & 0.537 \\
\hline
\end{tabular}

N.B.: The disferent capital liners in columns denote the presence of significant change

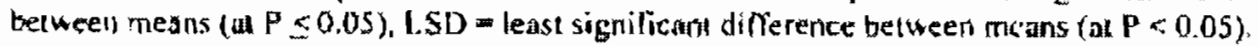


Table (6): Effets of mycotoxicosis and/or brucellasis on some serum biochemical constituents of buffaloes

\begin{tabular}{|c|c|c|c|c|}
\hline Troups & $\begin{array}{l}\text { ALT-enzynt } \\
\text { activicy } \\
\text { (I.ULL) }\end{array}$ & $\begin{array}{l}\text { Tolal } \\
\text { bilirubin } \\
\text { (ntedal.) }\end{array}$ & $\begin{array}{l}\text { Tolal } \\
\text { lipids } \\
\text { (g/dll.) }\end{array}$ & $\begin{array}{l}\text { Total } \\
\text { protein } \\
\text { (glu!.) }\end{array}$ \\
\hline $\begin{array}{l}\text { Control } \\
\text { (norinal) group }\end{array}$ & $\begin{array}{c}8.245 \pm 0.321 \\
A\end{array}$ & $\begin{array}{c}1.674 \pm 0.141 \\
A\end{array}$ & $\begin{array}{c}27.060 \pm 1.718 \\
A\end{array}$ & $\begin{array}{c}8.308 \pm 0.289 \\
\mathrm{AC}\end{array}$ \\
\hline $\begin{array}{l}\text { Mycoloxin } \\
\text { potsoned groups }\end{array}$ & $\begin{array}{c}8.910 \pm 0.430 \\
B\end{array}$ & $\begin{array}{c}1.765 \pm 0.267 \\
\mathrm{~A}\end{array}$ & $\begin{array}{c}34.116 \pm 1.303 \\
n\end{array}$ & $\begin{array}{c}7.023 \pm 0.287 \\
\mathrm{k}\end{array}$ \\
\hline $\begin{array}{l}\text { Brucella infected } \\
\text { growp }\end{array}$ & $\begin{array}{c}9.160 \pm 0.595 \\
B\end{array}$ & $\begin{array}{c}2.156 \pm 0.148 \\
4\end{array}$ & $\begin{array}{c}31.811 \pm 1.075 \\
C\end{array}$ & $\begin{array}{c}8.6 \overline{17 \pm 0.215} \\
A\end{array}$ \\
\hline $\begin{array}{l}\text { Brueclla infected } \\
\text { a mpcolurin } \\
\text { poisoned growp }\end{array}$ & $\begin{array}{c}10.920 \pm 0.357 \\
C\end{array}$ & $\begin{array}{c}2.238 \pm 0.173 \\
11\end{array}$ & $\begin{array}{c}39.392 \pm\{.17\} \\
D\end{array}$ & $\begin{array}{c}7.523 \pm 0.158 \\
C\end{array}$ \\
\hline LSD $(P<0.05)$ & 0.665 & 0.315 & 2.155 & 0,492 \\
\hline
\end{tabular}

N.B.: The different capibal liters in colunins denote the presence of significant change between incalus (at $\mathbf{P} \leq 0.05$ ). SD = Least significant difference (at $\mathbf{P} \leq 0.05$ ),

Table (7): Effects of mycotoxicosis and/or brucellosis on some serum biochemical constituents of cattle

\begin{tabular}{|c|c|c|c|c|}
\hline Groups & $\begin{array}{l}\text { ALT-tinzyme } \\
\text { activify } \\
\left(1, U_{n} / L\right)\end{array}$ & $\begin{array}{c}\text { Tolal } \\
\text { bilirubin } \\
\text { (mghil.) }\end{array}$ & $\begin{array}{l}\text { Totat } \\
\text { lipids } \\
\text { (gtally }\end{array}$ & $\begin{array}{l}\text { Tolal } \\
\text { Protein } \\
\text { (efdl.) }\end{array}$ \\
\hline $\begin{array}{l}\text { Conirol } \\
\text { (normal) groups. }\end{array}$ & $\begin{array}{c}14.500 \pm 1.166 \\
\mathrm{~A}\end{array}$ & $\begin{array}{c}1.728 \pm 0112 \\
\mathrm{~A} \\
\end{array}$ & $\begin{array}{c}26.779 \pm 1.334 \\
\mathrm{~A} \\
\end{array}$ & $\begin{array}{c}7.692 \pm 0.086 \\
\mathrm{~A} \\
\end{array}$ \\
\hline $\begin{array}{l}\text { Mycoloxin } \\
\text { poisoned groups }\end{array}$ & $\begin{array}{c}14.910 \pm 0.911 \\
\mathrm{~A}\end{array}$ & $\begin{array}{c}1.916 \pm 0.261 \\
A\end{array}$ & $\begin{array}{c}28.821 \pm 1.897 \\
\mathrm{~A}\end{array}$ & $\begin{array}{c}6.840 \pm 0.353 \\
\mathrm{~B} \\
\end{array}$ \\
\hline $\begin{array}{l}\text { Bruestla infecled } \\
\text { groums }\end{array}$ & $\begin{array}{c}16.620 \pm 0.825 \\
\mathrm{~A} \\
\end{array}$ & $\begin{array}{c}1.82+ \pm 0.2816 \\
A \\
\end{array}$ & $\begin{array}{c}29.119 \pm 1.318 \\
\mathrm{~A}\end{array}$ & $\begin{array}{c}8.364 \pm 0.410 \\
C\end{array}$ \\
\hline $\begin{array}{l}\text { Hrueella in Tecled } \\
\text { \& mycotoxin } \\
\text { Luisoned groups }\end{array}$ & $\begin{array}{c}18.33+ \pm 1.026 \\
A\end{array}$ & $\begin{array}{c}2.037 \pm 0.163 \\
A\end{array}$ & $\begin{array}{c}29.086 \pm 0.939 \\
t\end{array}$ & $\begin{array}{c}7.923 \pm 0.222 \\
A C\end{array}$ \\
\hline $\operatorname{LSD}\left(\beta^{\prime}<0.05\right)$ & NS & NS & $\mathrm{NS}$ & 0.537 \\
\hline
\end{tabular}

N.D.: The different capital litters in columns denote the presence of significant change between neans (at $P \leq 0.05$ ), LSD $=$ Least significant difference (at $P \leq 0.05$ ). 


\section{REFERENCES}

Adel Fattah, Sh, M.: Helal, A. D. and Shehata, F. I. (2004) : Some wcrum biochemical, Hormo* nal and protein clectrupheretical studies nu shecp) and goats suffering from myculoxdeo-

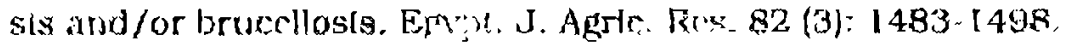

Alton, G. G.: Jones, L. M. and Pietz, D. E. (1975): Lilínhatory techniques in bructuosis, Who. Monograph serjes No. 55. WHO. Geneva. Stwilzertand.

Anon.; (1984): Instructions on concluding brucellesis renological Lests. NVSL. USUA. USA

Anonymous, (1992): Fungi and mycotoxins. In stored proceedings köo. \{369\}. Canlberra.

AOAC (Association of analytlcal chemlsts) (1980) : Omicial methods of analysis, 3rd ed. Wasluinglon, D.C. U.S.A.

Blood, B. C.; Handerson, J.A. and Radostits, O. M. (1979) : Velerinaly nedicinc 5lh cdition.

CAST (Council for Agricultural Sclences and Technology) (1989) : Mycotoxis: Economic and Ho:alth rigks, Taskle force report No. 115, Ames, lowa.

Challi, J. R. G.; Davies, 1. J. and KJJP. (1973) : Wndoctinol., (96): 185.

Cheung, C. Y. (1983) : Prolactin suppresses lulcinzing hormone sccretion and piluitary respanses of LHIH by a direct action at the anterlor pitultary. Endocrnol. (1)3\}: 632698.

Dietert, R. R.: Gureshl, M. M. and Bloom. S. E. (1985) : Embryanic cxpersuce to aflatoxtm-B1.: Mutagcnlcity and infucnce of dcvelopment and mmunlty. Envirors. Mutagen. (7): 715 725.

Dolezalova, V.; Strat I, P. and simlekova, M. (1983) : _-feto-protelns and macroglobulin as a markeis of distinct response of hepatocytes bo carchogens in the rat: carelnogenesis. Ann. N.Y. Scad, Scl. (417): 294-306.

Doumas, D. T.; Watson. W. A and Bige, H. G. (1971) : Kits used for serum total proteln deter111 Ination. Clin. Chcin. Acta, 31 (1): 87.

Georgieva. S. A (1989) : Essentials of physlology, pp: 256. Translated from Russtan by Nicolal Lydolmov, Mir Publishers, Moseow.

Ghosh, R. C,; Chauban, H. V. S. and Jha, G. J. (1991) : Suppression of cell mediated immunlty by purined anatoxin- Bl in broller cklcks. Vet. Immunol. Inimunopth. (28). 165-172.

Gordon. A. H. (1983) : Electroplinesis of proteins in polyacrylamide and starcli gels. In laboratory Lechnicjues in blochejnlstry and molectular blology. Elsever North Holand Blocheml- 
cal Press. Anesicrdam, pp: 213.

Harrison, L. R.; Colvln, B. M.; Green, J. J.; Newman, L, E. and Cole, J. R. (1990): Pulrnonary relcha and hydrothorax hi swine preduced by fumonsin- is a loxic metabolnte of fusariu[a monfllformc. J.VCt. Dlagn. Invest. (2); $217 \cdot 221$.

Helal, A D. and Abdel Fattah. Sh. M. (2003) : Btocliesilical, elextion uncroscopical and Inmu.

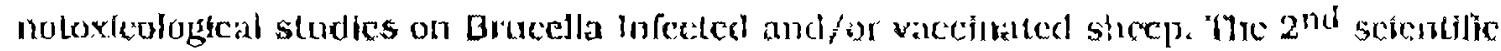

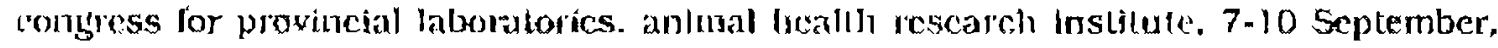
Egyptan d. Agic. Res. 81[1]: 50.71.

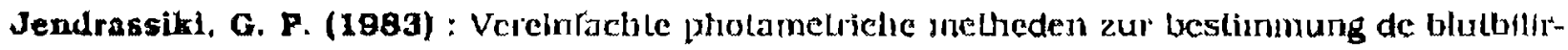
ubins, Biochemical. 2 (297): 81.

Kachman, J. F. aud Moss, D. W. (1976) : Clinteal biochemistry of donrestic animals, Aeademic press. Ine.

Kaneko, J. (1889) : Enzymes. In: laundamentils of elinfcal chemistry, 13p: 565-598., Saunders. Philathlyhia

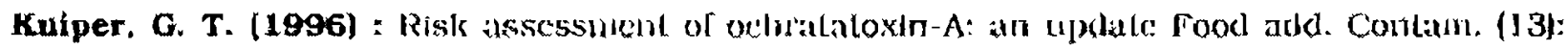
(Sipppl.): 53-57.

Miller, J. D. (1995) : Fungl and mycotorins in gralns. Implleatons for stored product researely. J. Slored Food Res. 31,1.

Osweiler, G. D.: Kehrl, M. E.; Stable, J. R.; Thurston, J. R.; Ros\&, P. F. and WLison, T. M, (1993) : Erects of fumonsin contaminated corn screenings on growth and healli of feeder eilves. J. Anint. Sol. (71): 459.

Radostlts, O. M.; Gay, C. C.; Blood, D. C. and Hinchelier, K. W. (2000) : Veterinary mediche "A lext bowk of the discases of callue, Sheep, Plgs and Horses", $9^{\text {llt }}$ cd..; w.B. Saunders Company LLd.

Reitman, S. and Frankel, 8. (1957) : Kits for determination of SGOT and SGPT. J. Clin. PaUh. (28): 56 .

Schalm. 0. (1975) : Veterinary hacmatology, London. Bailliere Tindall and Clinieal blochemistry of domestic animals, Acalemic press, lnc.

Sehmit. J. M. (1964) : Futs for detcrmination of senum Lotal liphd concentration. thesls, Lyon.

Snedecor, G. W. and Cochron, W. G. (1969) : Stausulcal methods. $6^{\text {th }}$ ed, lowa statc unlversily juress, Ames, JOWA.

Stroev, E. A (1986) : Blochemistry, English translation, Mir publishers, Moscow. 
Abdel Fattah, Sh.M.; et al...

Tung., H. T.: Wyatt, R. D.: Thaxton, P. and Hamliton. P. B. (1975) : Concedtiallon of serisn protelns allatoxicosis. Toxicol. Appl. Phamacol. $\{34\}: 320-326$.

Vajtukaltis. J. L.i Bermudez, A.J. and Cargile, C. M. (19go) : New evidence for an antiestrogenic antlom of domphene cltále in women. d. Chu. Endócrinol. Metab. (32): 503-508.

Young, D. S.; Pestaner, L. C. and Gibberman, V. (1975) : Eircels uf elrugs on clinical lahoralo. ry lests. Clinkeal Chem. $21(5): 431$. 
Abdel Fattah, Sh.M.; et al...

$$
\text { الملنحص العريحس }
$$

بعض الدراسات البيوكيميانية والهورمونية والفصل الكهيى لبروتين سصل الجاموس والبقو

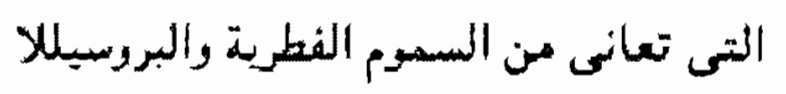

$$
\begin{aligned}
& \text { شعبان مصطفى عبدالفتاح، محسرد كسال مصطفى الديب"، سويفى عبدالرحيم سويفى*"، }
\end{aligned}
$$

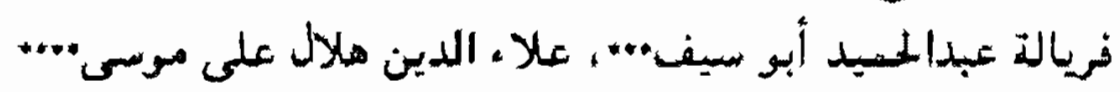

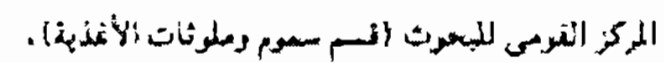

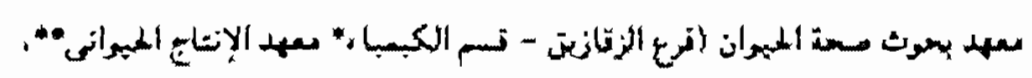

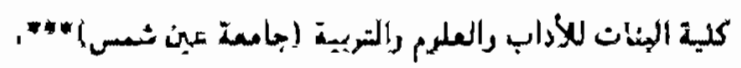

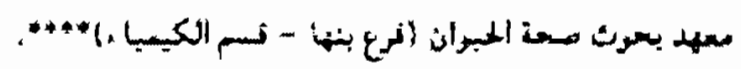

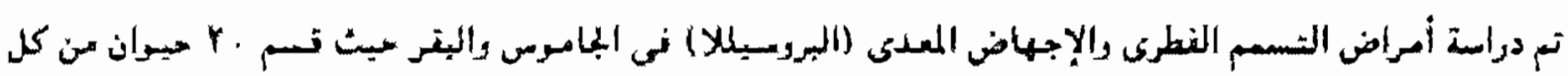

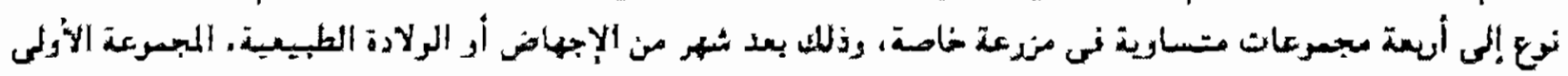

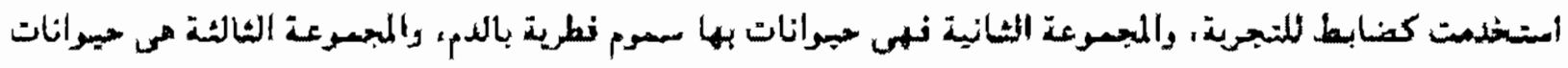

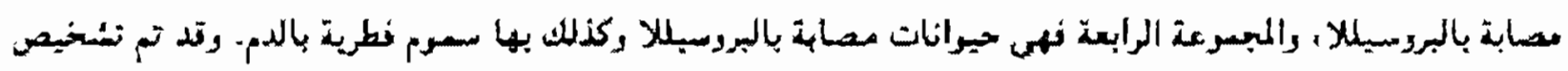

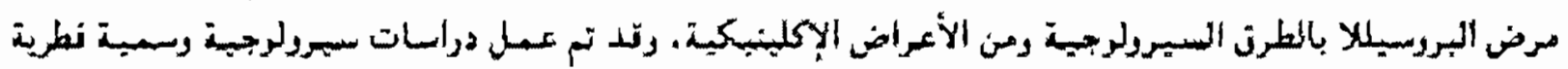

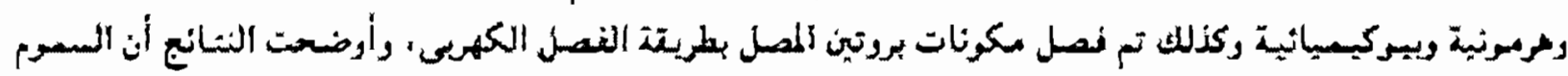

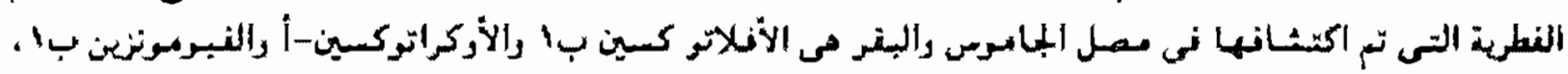

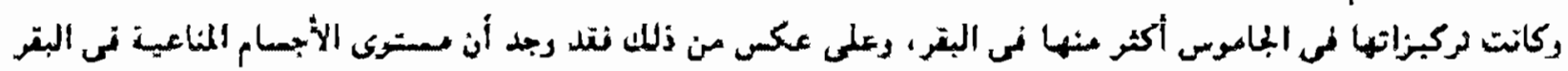

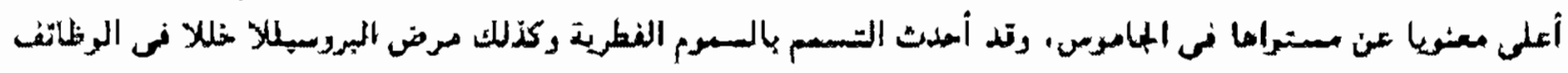

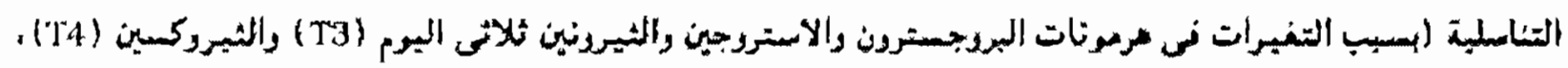

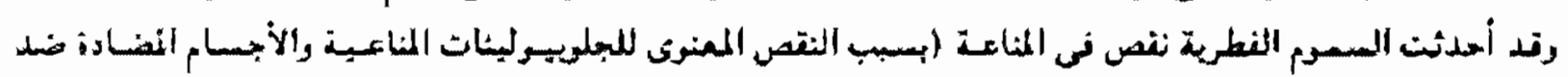

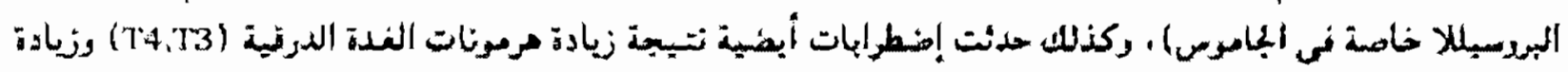

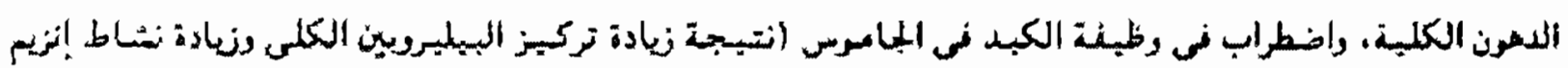
( ALT)

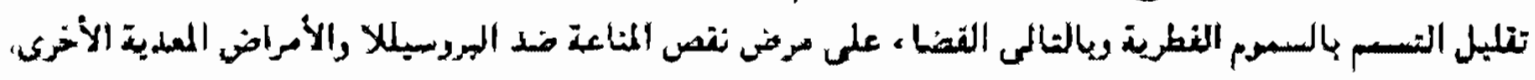

